\title{
An Exploratory Research on Country-of-Origin and Its Impact on the UAE Consumers Buying Decisions
}

\author{
Rajasekhara Mouly POTLURI ${ }^{1}$, Sophia JOHNSON ${ }^{2}$
}

Received: July 03, 2020 Revised: July 28, 2020 Accepted: August 10, 2020

\begin{abstract}
The purpose of the paper is to explore the country-of-origin (COO) influence on the buying decisions of the United Arab Emirates (UAE) consumers. The collected data from 370 consumers were summarized and coded by using Software R Studio and Microsoft Excel. The independent variables were analyzed and tested for their significant impact on the dependent variable, final buying decision of the product/ service based on its country of origin. The selected hypotheses tested by administering the Kruskal-Wallis (K-W) hypothesis testing technique. The researchers identified that UAE consumers buying decisions influenced mainly by the country of origin of the products and services. The demographic variables like age, education, country of origin influential factors, country of choice was not displaying any significant impact on the buying decisions of consumers. The survey is limited to cover the general consumers of the country who are randomly selected from Dubai and Sharjah emirates. The study is beneficial to all the types of marketers, including domestic and international companies, who have plans to know the exact influence on consumers' buying decisions. The present research paper is original and provides empirical evidence on the country of origin's impact on the buying decisions of different products/services in the UAE.
\end{abstract}

Keywords: Country-of-Origin, Buying Decisions, UAE Consumers, Kruskal-Wallis Testing Technique, United Arab Emirates

JEL Classification Code: M16, M31, N15

\section{Introduction}

In the era of globalization, every consumer in the world has an opportunity and a chance to enjoy multinational companies' products and services along with domestic. While selecting the required stuff to satisfy their needs, wants, and aspirations, most of the consumers would give first preference to their native country products and services over the foreign. The favorable opinion or attitude of the consumers of different countries consumers towards their

${ }^{1}$ First Author and Corresponding Author. Associate Professor, Management/Marketing, College of Business, Al Ghurair University, Dubai, United Arab Emirates [Postal Address: Academic City, P. O. Box. 37374, Dubai, United Arab Emirates]

Email: rajasekhara.potluri@agu.ac.ae

2Director, AGU Library, Al Ghurair University, Dubai, United Arab

Emirates. Email: sjohnson@agu.ac.aen

(C) Copyright: The Author(s)

This is an Open Access article distributed under the terms of the Creative Commons Attribution Non-Commercial License (https://creativecommons.org/licenses/by-nc/4.0/) which permits unrestricted non-commercial use, distribution, and reproduction in any medium, provided the original work is properly cited. local companies is a common phenomenon in every part of the globe based on some exceptions. In the new millennium, the world has witnessed a vital swing in the world economy from localization to glocalization with the globalization of markets, production, and extraordinary increase of crossborder trade have created the necessity of new research streams in the field of global marketing to the forefront. A considerable transformation has been taking place in the economic landscape of many emerging economies in the world, particularly BRICS countries since the 1990s. The changeover from a centrally planned financial system toward a free market economy has been responsible for the creation of numerous, diversified, and unsatisfied needs of people living in the region (Quelch et al., 1991).

One of the research streams is the "Country of origin" (COO) studies in which consumers/buyers' views and their evaluations of different products and services sourced both from developed and developing countries are analyzed. Bilkey and Nes (1982) published their classic research on the country of origin; after that, extensive research has been undertaking in this area of study from diverse continents in the world. Several research studies on the country of origin 
commenced particularly in the last three decades, have assessed the issue at the region, country, product, and specific brand levels. On the contrary, a limited number of studies have taken-up by researchers on consumers' perception of the product' s/service's country of origin, which is vital in identifying consumers' choice and consumption patterns. The most recent nationalistic economic measures introduced by the US President Trump and the potential trade war with China also an augury (Ewing, 2018) for once again review the concept in the context of the most crucial middle eastern country the United Arab Emirates. Based on the significance of the country of origin issue in recent years, especially to resource-scarce, developing countries along with the UAE in particular, the researchers have taken an initiation to explore whether the country of origin influence the buyer behavior of the UAE consumers or not.

\section{Literature Review}

Tan and Farley (1987) stated that COO was one of the most studied topics in international marketing. In the last decade, Usunier (2006) noticed that there were more than 800 scholarly publications dedicated to reporting studies in this area. Based on the present trend, significance, and intensity of the concept of country-of-origin, the research publications would cross more than 1200 by this year or next. Phau and Chao (2008) also expressed a similar kind of observation and said that $\mathrm{COO}$ research touched a turning point in its history in the context of globalization. Despite the remarkable number of publications on the issue and the reliable finding that origin matters (Verlegh \& Steenkamp, 1999), COO research such as a whole often said to be experiencing from a multiplicity of challenges, including methodological shortcomings (Samiee et al., 2005), a lack of conceptual clarity (Bloemer et al., 2009) and a tendency to be a theoretical (Samiee, 2011). The impacts of the country of origin on consumer purchasing have been extensively researched (Dinnie, 2004).

The country of origin effect is also known as the «made-in image» and the «nationality bias» (Cai, 2002). Research displays that consumers〉 wide-ranging universal insights of a country, including its national physiognomies, economic and political background, history, traditions, and demonstrative products, combine to create an overall name and fame or categorize that is then attached to the products of that country (Nagashima, 1970). For instance, a global study conducted by McCaskill (2016) of Nielsen, reported that country of origin fame has a significant influence on consumer perceptions and behaviors, and in circumstances in which additional evidence is unobtainable or complicated to obtain can be the lone determining factor of whether or not someone buys a product. Its effect is toughest on consumers who do not know much about the product or product type, and feeblest on well-informed consumers. Thoughtfulness to the country of origin varies by product category. It is the most reliable and most precise for durable goods (Jain, 2012) and luxury goods (Aiello et al., 2009) and weakest for "low involvement" product categories such as shampoo and candy (Urbonavičius \& Gineikienè, 2009).

In numerous surveys, it has also been recognized that the country-of-origin effect also applies to services (Peters, 2011). Several studies proved that consumers tend to have a relative preference to products from their own country (Shimp \& Sharma, 1987) or may have a relative fondness for or aversion against products that originate from specific countries (so-called affinity (Oberecker, 2008) and dislike (Klein, 1998) countries). Most of the researchers in the last two to three decades considered Country of origin (COO) as a significant focus of research (Acharya \& Elliott, 2001; Al-Sulaiti \& Baker, 1998; Fetscherin \& Toncar, 2010; Phau \& Chao, 2008). The product origin has become a more complicated construct while discussing the concepts of both countries of origin and ethnocentric tendencies of any country population. As said by Bhaskaran and Sukumaran (2007), due to multinational production and sourcing structures, products frequently relate to more than just one $\mathrm{COO}$ cue. The pervasiveness of such fusion products requires an apportioning of the original construct into separate dimensions such as country of assembly (COA), country of components (COC), and country of design (COD). The influencing of trade regimes in different countries, particularly developing countries, leads to manufacturers to continually evaluate localization and production structures.

Some of the researchers focus on the industry or a sectorspecific country of origin (COO) research in general (Sohail, 2005); Thanasuta et al., 2009). According to Haeubl (1996), findings from previous studies (Han \& Terpstra, 1988; Han, 1989) suggest significant "Made-in" effects for automobiles, and hence exciting results also for related consumer ethnocentric tendencies. Liefeld (1993) reported that the enormous $\mathrm{COO}$ effects are found for complex, fashionoriented, and expensive products such as automobiles and their components (Karunaratna \& Quester, 2007). The importance of country of origin is most considerable in the purchase of cars, clothing, and electronics, while it is of little importance in the purchase of household products, large appliances, and furniture (Jaffe \& Nebenzahl, 2001).

Brodowsky (1997) differentiates between ethnocentric and non-ethnocentric customers, studying the perceived morality of domestic and non-domestic purchasing decision and reported that $\mathrm{COO}$ effects could be understood only by taking consumer ethnocentrism into account-especially for highly ethnocentric customers where significant results on purchase intent can be found. Brodowsky (1997) also revealed that among consumers with low ethnocentrism, 
$\mathrm{COO}$ elucidates more of the differences for product appraisal than it does for mindset. These customers appear to use $\mathrm{COO}$ evidence as unbiased evidence to appraise the product, whereas extremely ethnocentric consumers use the cue as a tool to exhibit their patriotic emotion. Every marketer in every part of the globe should understand these complexities well as a prospective basis for market or customer segmentation.

Huddleston, Good, and Stoel (2001) surveyed on COO's influence on the perceived quality of cars, plus the relationships of consumer ethnocentrism and product necessity with perceived quality. The same study highlighted that the perceived quality of non-essential products such as automobiles, when having a developed country as $\mathrm{COO}$, is consistently rated more favorably than essential products, adding to the notion that $\mathrm{COO}$ is more prominent for nonessential products. Country of origin professed as a highly determinative cue that consumers use to make product evaluations (Insch \& McBride, 2004; Hamzaoui \& Merunka, 2006) and it influences which products consumers are willing to purchase and the amount that they are willing to pay for them (Koschate-Fischer et al., 2012).

There is a tremendous encouragement for the presence of $\mathrm{COO}$ influences on consumers' appraisals of products originating from overseas sources (Lala et al., 2009). Based on the last four to five decades of extensive research on $\mathrm{COO}$, a joint conclusion: a product's $\mathrm{COO}$ can influence consumers' evaluative judgments of the product (Pharr, 2005). COO effects have noticed to exist for commodities in general (Howard, 1989; Darling \& Wood, 1990), for specific product categories (Cordell, 1992; Roth \& Romeo, 1992), and particular brands (Han \& Terpstra, 1988; Chao, 1993; Tse \& Gorn, 1993). Considerable COO research has shown an inclination for consumers to choose their own country's products (Han, 1988; Hong \& Wyer, 1989; Papadopoulos et al., 1990).

Some other studies also have indicated that $\mathrm{COO}$ influences fluctuate corresponding to demographic variables (e.g., Anderson \& Cunningham, 1972; Dornoff et al., 1974; Wang, 1978; Schaefer, 1997). However, there is a shortage of unanimity in that respect. Ultimately, products from developed countries appear to experience benefits over their counterparts from developing countries (Leonidou et al., 1999). COO study directs on buyer's opinions concerning the similar traits of goods and services manufactured in various countries (Heslop \& Papadopoulos, 1993). One can distinguish the results of instances in the existing marketing literature (e.g., Al-Sulaiti \& Baker, 1998; Bilkey \& Nes, 1982; Kaynak \& Cavusgil, 1983; Laroche et al., 2005; Peterson \& Jolibert, 1995; Verlegh \& Steenkamp, 1999). Automobiles, particularly cars from the US, Japan, and German, and French wines are perceived and evaluated differently from Italian cars, Taiwanese electronics, Greek wines. In different countries, consumers may come up with different product country preferences.

Products from European countries (especially German products) were exposed to a significant number of studies in the COO research history. The survey of Al-Sulaiti and Baker (1998) stated that Schooler (1971) noticed that American consumers rated German products better than those of Asia, India, and Western Europe. Dornoff et al. (1974) also demonstrated that Germany was rated the highest in mechanical products by American consumers. Nagashima (1970) compared the attitudes of American and Japanese businessmen and realized that Japanese rated "made in Germany" as the best while Americans gave the highest rating to household products. Bannister and Saunders (1978) identified that favorable images attached to West Germany, the UK, and Japanese products, mediocre images to products "made in" France, Italy, and the USA; and inferior images of products "made in Russia."

Yavas and Alpay (1986) said Saudi Arabian and Bahraini consumer attitudes towards "made in" USA, Japan, France, Germany, Italy, UK, and Taiwan and identified that the Taiwan label was evaluated the lowest while Japan was rated the highest followed by the USA and Germany. Lawrence et al. (1992) found New Zealand consumers' attitudes towards automobiles sourced from four different countries: Japan, Germany, France, and Italy and found that German cars favored the most. Keown and Casey (1995) identified that Northern Ireland consumers rated the traditional wine producers such as France, Italy, and Germany the highest, and the USA and the UK, the lowest.

Badri et al. (1995) researched consumers in the Gulf States and observed "Made in the USA, Japan, and Germany" as the most favored countries, and within European products, German products were indicated as the first choice. Another researcher Sohail (2005), said that Malaysian consumers preferred German-made products are perceived in general to be of high quality. Schweiger et al. (1995) proved that "made in Europe" label and compared consumers' perceptions of the quality of various products within this label to the quality of goods marked "made in the USA" and "made in Japan." Results indicated that European products labeled "made in Europe" were perceived to be the lower quality from "made in Japan" and "made in the USA." Some of the previous studies also suggested that the $\mathrm{COO}$ effect may vary with different product categories. For instance, electronic things from Italy might be perceived poorly. However, Italian shoes would receive high marks from consumers of different parts of the world. As said by the researchers Kaynak and Cavusgil (1983), Canadian consumers showed perceptual biases across product classes such as electronics, food items, fashion merchandise, and household goods. Evidence also indicates that the image of a country can be recognized differently by customers in different countries. 
Cattin et al. (1982) reported that Americans perceived German and Japanese-labeled products more favorably than the French. Some researchers identified significant attributable differences based on the economic environment found in each country, the sample characteristics and the intensity of multinational marketing activity undertaken by the companies from the exporting countries (Lin \& Sternquist, 1994). More substantial COO effects may exist for products from a country with dissimilar belief systems in comparison to the products from a similar country (Zhang, 1996), such as a Georgian consumer appreciate German product culture. Germany used to be known as a country for high-quality products through the technological development of Western Europe.

\subsection{Theoretical Framework}

Prominent scholars like Ernst Dichter and Robert Schooler first explored the subject here and now extensively recognized as the "country-of-origin" (COO). The introduction of landmark concept $\mathrm{COO}$ concurs with the 30th anniversary of Levitt's (1983) highly influential research article in the Harvard Business Review that promoted the concept of "globalization." Extensive research has taken place since the 1960s on the origin of the product or country and its importance. Scholars adopted the term "country-oforigin" or $\mathrm{COO}$, which is the country where the product is produced initially or where its corporate headquarters are located (Johansson et al., 1985; Ozsomer \& Cavusgil, 1991). From the early 1990s, extensive globalization has taken place in every business, and firms have identified the importance of reducing the costs mostly related to all kinds of raw materials, and labor.

The country of origin of a product is able to have several possible definitions. It can refer to Hanes and Wolcott (2016) (a) "the place from which the merchandise was directly received; that is the last border crossed or port entered before reaching its final destination; (b) the country of the consignment (i.e., from where the goods were sold); or, (c) the country of original growth or extraction." $\mathrm{COO}$ is an adventitious element that sways the apparent quality and value of a product, the risk coupled with it, and consumers' inclinations and intention to purchase it (Ahmed \& d'Astous, 2008; Peterson \& Jolibert, 1995). Since Schooler's pivotal 1965 article, the COO effect has increasingly been written about (Usunier, 2006), appearing to influence buyers' evaluations and perceptions, and the perceived image of products (Opoku \& Akorli, 2009).

Numerous countries of origin can depict a single product: country-of-design, country-of-production, and country-ofassembly (Samiee, 1994). COO that relates to a product by the consumer, even if this association does not deal with certainty (Samiee et al., 2005). Thakor and Kohli (1996) establish the concept of brand origin as the place, region, or country to which the brand is recognized to belong by its target consumers. $\mathrm{COO}$ affects consumers' assessment of a product through the country's image, depicted as the set of typecasts held by consumers about that country and transforming the buying decision. These typecast refer to a link in consumers' minds between a type of product, and a nation seems to have proven know-how and reputation for this. Cestre and Usunier (2007) presented the concept of product ethnicity, described as a robust relationship between a product and a country. The association between a product and a country arises from issues showcasing the $\mathrm{COO}$ of the product, such as its cultural, social, and political systems, or degree of technological and economic development (Roth \& Diamantopoulos, 2009). Most surveys on the COO effect involve consumers in developed countries (Saffu \& Scott, 2009), who tend to prefer domestic products due to confidence in their quality and feelings of national pride, patriotism, and ethnocentrism (Balabanis \& Diamantopoulos, 2008).

Figure 1 introduces a framework synthesizing the different factors behind the preference of imported products in a country like the United Arab Emirates. The primary constructs are symbolic meanings related to $\mathrm{COO}$ (Batra et al., 2000; Ger \& Belk, 1996), economic factors (Batra et al., 2000; Saffu \& Walker, 2006), cultural flows (Guo, 2013) and history (Agbonifoh \& Elimimiam, 1999; Batra et al., 2000; Ustuner \& Holt, 2010).

In most of the emerging countries, consumers' preference for imported goods is primarily driven by the symbolic meanings related to $\mathrm{COO}$, caused by economic factors, cultural flows, and history. The symbolic meanings that consumers associate with western products in developing countries are a significant determinant of their preference for imported goods (Marcoux et al., 1997). In these countries, the values coupled with community status passionately sway consumption by extracting conspicuousness and status symbols. Imported products-more is luxurious and rarer than local goodsare contemplated to be icons of stature and to bestow exalted prestige to their owners (Kaynak et al., 2000). The aspiration to acquire such goods is augmented by the low standard of living, meaning that most consumers must buy local products (Batra et al., 2000). COO is sometimes considered the most crucial attribute of a product, given its capacity to confer social status (Batra et al., 2000); Kumara \& Canhua, 2010; Opoku \& Akorli, 2009). When consumers have a reliable buying power, they choose international products to distinguish themselves from the masses and to imitate western consumption practices and lifestyles (Ustuner and Holt, 2010). 


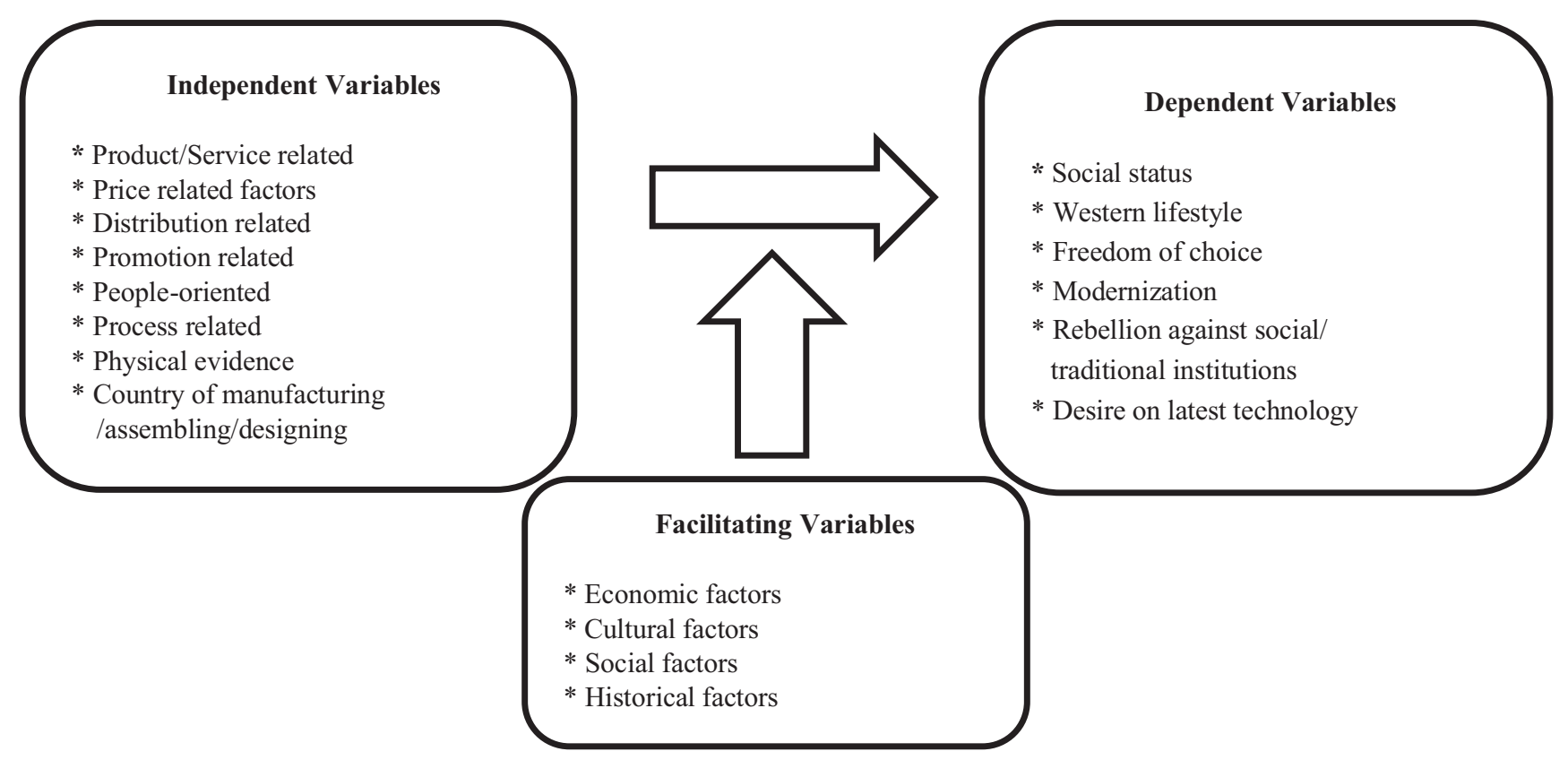

Figure 1: A Priori Framework for Consumers Preference for Imported Products/Services

\subsection{Hypotheses}

Based on the extensive literature review, theoretical framework, and the data collected through the investigations, the researchers generated the following list of hypotheses.

H1: Age has a significant impact on the interpretation of buying behavior of product/service concerning its COO.

H2: The final buying decision of a product/service is based on its COO, is mostly influenced by gender.

H3: Emirate at work substantially sway the buying behavior of product/service concerning its COO.

H4: Education significantly influences the final buying decision of a product/service based on COO.

H5: COO influencing factors considerably impacts the final buying behavior of product/service.

H6: The choice of country noticeably influences the buying behavior of products/services regarding its COO.

\section{Research Methods}

This research was originated by the researchers to know the country-of-origin (COO) influence on the purchase decision of the UAE consumers. The researchers believed that empirical analysis is crucial to examine the problem statement with more precision comprehensively and planned to determine significances to understand the COO's influence on the UAE consumers' buying decision. The researchers collected more than thirty research and review articles based on which extensive literature review and theoretical framework completed for identifying the factors influencing consumer behavior based on the country of origin of the product or service.

Following a detailed, relevant literature review and conceptual framework, the researchers selected six hypotheses and prepared a comprehensive questionnaire with two parts. The first part of the survey highlights information about the demographic profile of respondents, whereas the second provides information about the list of comprehensive factors influencing the UAE consumers' buying decision. The researchers directed a convenience and stratified random sampling methods to gather the opinion of three hundred and seventy (370) consumers, mostly from the Dubai and Sharjah emirates of the United Arab Emirates. The researchers received all the circulated 370 questionnaires with proper responses to all the columns with special care taken in getting the in advance time of the respondents. The collected data carefully summarized, coded, and controlled by governing Software R Studio and Microsoft Excel. The unbiased variables were analyzed and tested for their significant impact on the dependent variable, final buying decision of the product/service based on its country of origin. The selected hypotheses tested by applying the KruskalWallis (K-W) hypothesis testing technique was used to analyze the data. Alongside the survey, the researchers also organized personal interviews based on the respondents' time to know more about their buying motives based on the country of origin of the products/services. 


\section{Results and Discussion}

This fourth part of the research highlights the research milieu, analytical part of the primary data along with a demographic profile of the total three hundred and seventy respondents, and in the final section of this part presented the four hypotheses testing results.

\subsection{Research Context}

The research focuses on the United Arab Emirates (UAE) is a constitutional federation of seven emirates viz., Abu Dhabi, Dubai, Sharjah, Ajman, Fujairah, Ras al Khaimah, and Umm al Quwain and the city of Abu Dhabi considered as the capital of the country. The UAE is ideally a stable country in terms of politics, and economy-wise and holds the 25th position globally in Global Competitiveness Report 2019 by World Economic Forum. The country>s soft policy earned the UAE, the first rank in Passport Index. Besides, it stands out as one of the ten largest donor states in official development aid (ODA). Recognized as a tolerant country, the UAE hosts more than 200 nationalities doing business, living, learning, and touring the UAE. Residents enjoy the freedom of civil rights and the practice of religion (https:// www.government.ae/en/about-the-uae/fact-sheet). A country like the UAE characterized by an ambivalent reconciliation of both Islamic and Western cultures, values, and behavioral tendencies would be the best test market for both domestic and multinational companies along with similarities with its neighboring countries mostly other Gulf Cooperation Council (GCC) like Saudi Arabia, Kuwait, Bahrain, Oman, Qatar.

\subsection{Demographic Profile of the Respondents}

The study completed with a sample of 370 consumers from the emirates of only Dubai and Sharjah (see Table 1) only. The accumulated data was cleaned and evaluated statistically, applying the R language in R Studio. Primarily, by administering the Microsoft Excel, the researchers have taken-up the cleaning process partially before importing the data into the statistical computing tool, R Studio. The dependent variable in the data, country of origin's (COO) influence on the buying behavior of the UAE consumers, provides a critical path for analysis in the research.

\subsection{Statistical Analysis}

This dependent variable in the data determines the ultimate COO's sway on the consumer's decision making in the UAE. Out of the total three hundred and seventy respondents, surprisingly, everyone responded positively and said that country-of-origin influence is there on their buying behavior. The responses received from the stated number of respondents on the following areas or factors viz., product, price, distribution, promotion, process, and physical evidence along with the country of manufacturing, country of assembling, and country of design issues which are mostly influencing the question of choosing a product or service based on the country of origin. The researchers have given an option of 'select one' in the above said and raised one more closed-end question on the country of choice by offering the list of top five exporting countries like India, China, USA, Germany, and Japan along with European Union countries to the United Arab Emirates.

Table 1: Demographic Profile of the Respondents $(\mathrm{N}=370)$

\begin{tabular}{|c|c|c|c|}
\hline Demographic Variable & Classification & $\mathrm{N}=370$ & Percentage \\
\hline \multirow{4}{*}{ 1. Age (in years) } & Less than 33 & 242 & 65.41 \\
\hline & $\begin{array}{l}\text { Greater than or Equal to } 33 \text { and } \\
\text { Less than } 42\end{array}$ & 95 & 25.67 \\
\hline & Greater than or Equal to 42 & 33 & 8.92 \\
\hline & Total & 370 & 100.00 \\
\hline \multirow{3}{*}{ 2. Gender } & Male & 221 & 59.73 \\
\hline & Female & 149 & 40.27 \\
\hline & Total & 370 & 100.00 \\
\hline \multirow{3}{*}{ 3. Education } & Bachelors & 215 & 58.11 \\
\hline & Masters and above & 155 & 41.89 \\
\hline & Total & 370 & 100.00 \\
\hline \multirow{3}{*}{ 4. Emirate work status } & Dubai & 239 & 64.59 \\
\hline & Sharjah & 131 & 35.41 \\
\hline & Total & 370 & 100.00 \\
\hline
\end{tabular}


As mentioned in Table 2, the USA has received a prominent response from the consumers of this part of the Middle East to buy software products and services for all types of purposes, industrial products, and consumer durables, whereas China has received an abysmal response with a meager 4.32 percentage.

Eventually, after collecting the data which is ready to test and determine the driven assumptions, Kruskal-Wallis $(\mathrm{K}-\mathrm{W})$ Hypothesis testing is used in this research. The K-W test, also called a one-way Analysis of Variance (ANOVA), is a method for testing whether samples originate from the same distribution in the data (Kruskal \& Wallis, 1952). This technique applied to compare two or more independent samples of equal or sample sizes. The researchers employed the $\mathrm{K}-\mathrm{W}$ test to examine the chosen hypotheses, which illustrates the relation between a dependent variable, the final decision of women employees, and the remaining independent variables stated in the premises.

Besides the surveys, the investigators also engaged in unstructured personal conversations with the subjects who have given their valuable time. Most of the respondents also expressed that crucial macro-environmental factors like cultural, social, economic, legal, and governmental, some international factors influenced their purchasing behavior and said that they have unique interests to buy products and services with halal certifications. At the time of personal interactions, most of the respondents stated that a clear demarcation they are following while choosing different products and services. For instance, for buying consumer durables like cars, fashionable designer dresses, consumer entertainment electronic products, the UAE consumers' first preference is only developed countries like Japan, Germany, and the USA. At the same time, most of the consumers have chosen the perishables like vegetables, milk and its byproducts, fruits, cereals, rice, and spices mostly from India.

Table 2: Respondents Choice based on the Products/ Services Country of Origin $(\mathrm{N}=370)$

\begin{tabular}{|l|l|c|c|}
\hline No. & $\begin{array}{l}\text { Respondents Choice of } \\
\text { Country }\end{array}$ & $\mathbf{N = 3 7 0}$ & Percentage \\
\hline 1. & India & 25 & 6.76 \\
\hline 2. & China & 16 & 4.32 \\
\hline 3. & $\begin{array}{l}\text { United States of American } \\
\text { (USA) }\end{array}$ & 135 & 36.49 \\
\hline 4. & Germany & 91 & 24.60 \\
\hline 5. & Japan & 87 & 23.51 \\
\hline 6. & $\begin{array}{l}\text { European Union (except } \\
\text { Germany) }\end{array}$ & 16 & 4.32 \\
\hline $\begin{array}{l}\text { Total Responses on Country of } \\
\text { Choice }\end{array}$ & 370 & 100.00 \\
\hline
\end{tabular}

Surprisingly, China has received the lowest attention, and consumers opted primarily for small industrial products, but everyone accepted their commitment towards the UAE's infrastructural developmental programs in diverse fields.

\subsection{Testing of Hypotheses}

Table 3 illustrates the implementation of the KruskalWallis hypothesis testing, which strengthens the data collected both statistically and meaningfully. The P-Value from the result of this statistical test will decide to either approve or disprove the stated hypotheses.

The K-W hypothesis testing implemented to determine whether the selected demographic factors like age, gender, Emirati status, education, along with the country of choice impact on the buying habits of the UAE consumers. If this $\mathrm{P}$-value, resulting from the $\mathrm{K}-\mathrm{W}$ hypotheses testing, has a value of greater than 0.05 , the null-hypotheses $(\mathrm{H} 0)$ is approved. In the other case, if P-value is less than or equal to 0.05 , the alternative hypotheses (H1) are accepted. In explaining the overall results of the research, age (P-value 0.0081 ), education (P-value 0.0167), country of origin factors (P-value 0.00005$)$, and the country of choice (P-value 7.46e-.06) do not have a noteworthy impact on the buying behavior of the UAE consumers concerning the country of origin in purchasing various products and services. Whereas, the gender with a P-value of 0.1955 and Emirati at work (P-value 0.1715 ) significantly influences the buying behavior of the consumers from the United Arab Emirates to keep in mind the country of origin.

\section{Managerial Implications}

The outcomes of the research are in stripe with empirical studies from marketing (Zolfagharian et al., 2014; Zolfagharian \& Sun, 2010) and sociology (Rockquemore \& Brunsma, 2002) that find bicultural consumers to possess mixed identities and to draw upon these identities when evaluating different products. For leaders of all kinds of business, both channels of distribution and physical distribution companies and communications agencies can use the results of the study for segmentation, targeting, and positioning of their products and services by introducing a range of short and long-term decisions. The research highlighted the information about the exact buying motive of the UAE consumers keeps in mind the country of origin. The buying motive optional chosen by the consumers' community of this part of the Middle Eastern giant, helpful to marketers and stakeholders of the business to clearly understand the pace of consumer acculturation. 
Table 3: Testing of Hypotheses

\begin{tabular}{|c|c|c|c|}
\hline No. & $\begin{array}{l}\text { Null \& Alternative Hypothesis } \\
\text { (H0 \& H1) }\end{array}$ & $\begin{array}{l}\text { Proportionality } \\
\text { Test Result }\end{array}$ & Interpretation \\
\hline \multirow{2}{*}{1} & $\begin{array}{l}\text { HO: Age does not have a significant impact on } \\
\text { the interpretation of buying behavior of product/ } \\
\text { service concerning its COO. }\end{array}$ & \multirow{2}{*}{$\begin{array}{l}\text { K-W Chi-Squared } \\
\text { value: } 6.96 \\
\text { P-Value: } 0.0081\end{array}$} & \multirow{2}{*}{$\begin{array}{l}\text { Since the P-value is not statistically } \\
\text { significant }(<0.05) \text {, the null hypothesis }(\mathrm{H} 0) \\
\text { is rejected. } \\
\text { Thus, age does not have a significant } \\
\text { impact on the buying behavior of product/ } \\
\text { service concerning its COO. }\end{array}$} \\
\hline & $\begin{array}{l}\mathrm{H} 1 \text { : Age has a significant impact on the } \\
\text { interpretation of buying behavior of product/ } \\
\text { service concerning its COO. }\end{array}$ & & \\
\hline \multirow{2}{*}{2} & $\begin{array}{l}\mathrm{HO} \text { : The final buying decision of a product/ } \\
\text { service is based on its COO, is not mostly } \\
\text { influenced by gender. }\end{array}$ & \multirow{2}{*}{$\begin{array}{l}\text { K-W Chi-Squared } \\
\text { value: } 1.67 \\
\text { P-Value: } 0.1955\end{array}$} & \multirow{2}{*}{$\begin{array}{l}\text { Since the P-value is statistically significant } \\
(>0.05) \text {, the null hypothesis }(\mathrm{H} 0) \text { is failed to } \\
\text { get rejected. } \\
\text { Thus, gender significantly influences the } \\
\text { final buying decision of a product/service } \\
\text { based on its COO. }\end{array}$} \\
\hline & $\begin{array}{l}\mathrm{H} 1 \text { : The final buying decision of a product/ } \\
\text { service is based on its COO, is mostly } \\
\text { influenced by gender. }\end{array}$ & & \\
\hline \multirow{2}{*}{3} & $\begin{array}{l}\text { HO: Emirate at work substantially does not } \\
\text { sway the buying behavior of product/service } \\
\text { concerning its COO. }\end{array}$ & \multirow{2}{*}{$\begin{array}{l}\text { K-W Chi-Squared } \\
\text { value: } 1.87 \\
\text { P-Value: } 0.1715\end{array}$} & \multirow{2}{*}{$\begin{array}{l}\text { Since the P-value is statistically significant } \\
(>0.5) \text {, the null hypothesis }(\mathrm{H} 0) \text { failed to get } \\
\text { rejected. } \\
\text { Thus, the final buying behavior of product/ } \\
\text { service concerning its COO is significantly } \\
\text { impacted by the Emirate at Work. }\end{array}$} \\
\hline & $\begin{array}{l}\mathrm{H} 1 \text { : Emirate at work substantially sway the } \\
\text { buying behavior of product/service concerning } \\
\text { its } \mathrm{COO} \text {. }\end{array}$ & & \\
\hline \multirow{2}{*}{4} & $\begin{array}{l}\text { HO: Education significantly influences the final } \\
\text { buying decision of a product/service based on } \\
\text { COO. }\end{array}$ & \multirow{2}{*}{$\begin{array}{l}\text { K-W Chi-Squared } \\
\text { value: } 5.72 \\
\text { P-Value: } 0.0167\end{array}$} & \multirow{2}{*}{$\begin{array}{l}\text { Since the P-value is not statistically } \\
\text { significant }(<0.5) \text {, the null hypothesis }(\mathrm{H} 0) \text { is } \\
\text { rejected. } \\
\text { Thus, Final buying decision of a product/ } \\
\text { service based on its COO is not significantly } \\
\text { influenced by the Education }\end{array}$} \\
\hline & $\begin{array}{l}\text { H1: Education significantly influences the } \\
\text { buying decision of a product/service based on } \\
\text { COO. }\end{array}$ & & \\
\hline \multirow{2}{*}{5} & $\begin{array}{l}\mathrm{HO} \text { : COO influencing factors do not } \\
\text { considerably impact the final buying behavior } \\
\text { of product/service. }\end{array}$ & \multirow{2}{*}{$\begin{array}{l}\text { K-W Chi-Squared } \\
\text { value: } 16.47 \\
\text { P-Value: } 0.00005\end{array}$} & \multirow{2}{*}{$\begin{array}{l}\text { Since the } \mathrm{P} \text {-value is not statistically } \\
\text { significant }(<0.5) \text {, the null hypothesis }(\mathrm{H} 0) \text { is } \\
\text { rejected. } \\
\text { Thus, COO influencing factors do not } \\
\text { significantly impact the final buying behavior } \\
\text { of product/service }\end{array}$} \\
\hline & $\begin{array}{l}\text { H1: COO influencing factors considerably } \\
\text { impacts the final buying behavior of product/ } \\
\text { service. }\end{array}$ & & \\
\hline \multirow{2}{*}{6} & $\begin{array}{l}\mathrm{HO} \text { : The choice of the country does not } \\
\text { noticeably influence the buying behavior of } \\
\text { products/services regarding its COO. }\end{array}$ & \multirow{2}{*}{$\begin{array}{l}\text { K-W Chi-Squared } \\
\text { value: } 20.07 \\
\text { P-Value: } 7.46 e-06\end{array}$} & \multirow{2}{*}{$\begin{array}{l}\text { Since the P-value is not statistically } \\
\text { significant }(<0.5) \text {, the null hypothesis }(\mathrm{HO}) \text { is } \\
\text { rejected. } \\
\text { Thus, the choice of the country does not } \\
\text { noticeably influence the buying behavior of } \\
\text { product/service regarding its COO }\end{array}$} \\
\hline & $\begin{array}{l}\mathrm{H} 1 \text { : The choice of country noticeably influences } \\
\text { the buying behavior of products/services } \\
\text { regarding its COO. }\end{array}$ & & \\
\hline
\end{tabular}

Our research is also beneficial to export and import business houses that have extensive plans to continue their business with the UAE companies, along with different governmental authorities. The research also has additional implications at the societal level of the country, based on which anybody can understand the exact ethnocentric tendencies of the Emiratis. Because of the UAE's multicultural, multi-ethnic, multi-language societies of the $21^{\text {st }}$ century, it is an arduous task for any local businesses to introduce "buy local" campaigns because of the country's globalization policy and the same would proffer multiple opportunities to international trade. The research revealed the information about the country of choice based on the options given with the top five importing countries to the country from which different countries can develop and design strategies to tap these kinds of markets. 


\section{Conclusion, Limitations, and Directions for Future Research}

Even though UAE consumers are not showing significant importance to the country of origin of the products/ services, at the time of actual buying, consumers are clearly opting mostly from the USA products and services. The demographic variables like age, education, COO influential factors, country of choice were not displaying any significant impact on buying decisions of this part of consumers. At the same time, gender and Emirati status evidently influenced the buying decisions of the UAE consumers based on the country of origin of products and services.

The principal limitation of the study is that the respondents were selected only from the two Emirates of the United Arab Emirates viz., Dubai, and Sharjah, with the overall influence of country of origin on the purchase of products and services. Even though Arabic is the primary language in the country, the researchers completed the research only with the English questionnaire. There is no classification of products and services considered and followed by the researchers.

There will be further research opportunities based on any product or service classification. Future research should study other emirates like Abu Dhabi, Ajman, Fujairah, Ras al Khaimah, and Umm al Quwain with perfect stratification of region, types, and a class of consumers with the considerable magnitude of the sample. Along with the above, future research also should study other population segments, including those in rural areas and upper/lower social classes. An Additional likelihood for potential exploration is to analyze county of origin impact based on the specific product and service category. The choice of products or services is entirely at the discretion of the researchers.

\section{References}

Acharya, C., \& Elliott, G. (2001). An examination of the effects of 'country-of-origin' and 'country-of-assembly' on quality perceptions and purchase intentions. Australasian Marketing Journal, 9(1), 61-75.

Agbonifoh, B. A., \& Elimimiam, J. U. (1999). Attitudes of developing countries towards country-of-origin products in an era of multiple brands. Journal of International Consumer Marketing, 11(4), 97-116.

Ahmed, S. A., \& d'Astous, A. (2008). Antecedents, moderators and dimensions of country-of-origin evaluations. International Marketing Review, 25(1), 75-106.

Aiello, G., Donvito, R., Godey, B., Pederzoli, D., Wiedmann, K. P., Hennigs, N., Siebels, A., Chan, P., Tsuchiya, J., Rabino, S., \& Ivanovna, S. I. (2009). An international perspective on luxury brand and country-of-origin effect. Journal of Brand Management, 16(5-6), 323-337.
Al-Sulaiti, K. I., \& Baker, M. J. (1998). Country of origin effects: a literature review. Marketing Intelligence \& Planning, 16(3), 150-99.

Anderson, W. T., \& Cunningham, W. H. (1972). Gauging foreign product promotion. Journal of Advertising Research, 12(1), 29-34.

Badri, M. A., Davis, D. L., \& Davis, D. F. (1995). Decision support for global marketing strategies: the effect of country of origin product evaluation. Journal of Product \& Brand Management, 4(5), 49-64.

Balabanis, G., \& Diamantopoulos, A. (2008). Brand origin identification by consumers: a classification perspective. Journal of International Marketing, 16(1), 39-71.

Bannister, J. P., \& Saunders, J. A. (1978). UK consumers' attitudes towards imports: the measurement of national stereotype image. European Journal of Marketing, 12(8), 562-70.

Batra, R., Ramaswamy, V., Alden, D. L., Steenkamp, J. B. E. M., \& Ramachander, S. (2000). Effects of brand local and nonlocal origin on consumer attitudes in developing countries. Journal of Consumer Psychology, 9(2), 83-95.

Bilkey, W., \& Nes, E. (1982). Country-of-Origin effects on product evaluations. Journal of International Business Studies, 13(1), 89-100.

Bloemer, J., Brijs, K., \& Kasper, H. (2009). The COO-ELM model: a theoretical framework for the cognitive processes underlying country of origin-effects. European Journal of Marketing, 43(1-2), 62-89.

Brodowsky, G. H. (1997). The role of country of origin in consumer purchase decisions: development and testing of a comprehensive theoretical model. PhD Dissertation. State University of New York at Buffalo, Buffalo, NY.

Cai, Y., Cude, B., \& Swagler, R. (2002). Country-of-origin effects on consumers' willingness to buy foreign products: an experiment in consumer decision making. Doctoral dissertation. University of Georgia, Athens, GA.

Cattin, P., Jolibert, A. J., \& Lohnes, C. (1982). A cross-cultural study of 'made in' concept. Journal of International Business Studies, 13(3), 131-141.

Cestre, G., \& Usunier, J. C. (2007). Product ethnicity: revisiting the match between products and countries. Journal of International Marketing, 15(3), 32-72.

Chao, P. (1993). Partitioning country of origin effects: consumer evaluations of a hybrid product. Journal of International Business Studies, 24(2), 291-306.

Cordell, V. (1992). Effects of consumer preferences of foreignsourced products. Journal of International Business Studies, 23(2), 21-69.

Darling, J. R., \& Wood, V. R. (1990). A longitudinal study comparing perceptions of the US and Japanese consumer products in a third/neutral country: Finland 1975 to 1985. Journal of International Business Studies, 21(3), 427-450. 
Dinnie, K. (2004). Country-of-origin 1965-2004: a literature review. Journal of Customer Behavior, 3(2), 165-213.

Dornoff, R., Tankersley, C., \& White, G. (1974). Consumers' perceptions of imports. Akron Business \& Economic Review, $5,26-29$.

Ewing, J. (2018). US Allies jostle to win exemptions from trump tariffs. The New York Times, March 16, Retrieved March 19, 2020, from: www.nytimes.com

Fact Sheet. (2019). Fact sheet. The UAE Government. Retrieved March 24, 2020, from: https://www.government.ae/en/aboutthe-uae/fact-sheet.

Fetscherin, M., \& Toncar, M. (2010). The effects of the country of brand and the country of manufacturing of automobiles: an experimental study of consumers' brand personality perceptions. International Marketing Review, 27(2), 164-178.

Ger, G. \& Belk, R. W. (1996). I'd like to buy the world a coke: consumption scapes of the less affluent world. Journal of Consumer Policy, 19(3), 271-304.

Guo, X. (2013). Living in a global world: influence of consumer global orientation on attitudes toward global brands from developed versus emerging countries. Journal of International Marketing, 21(1), 1-22.

Haeubl, G. (1996). A cross-national investigation of the effects of country of origin and brand name on the evaluation of a new car. International Marketing Review, 13(5), 59-75.

Hamzaoui, L., \& Merunka, D. (2006). The impact of country of design and country of manufacture on consumer perceptions of bi-national products' quality: an empirical model based on the concept of fit. Journal of Consumer Marketing, 23(3), 145-155.

Han, C. M. (1988). The role of consumer patriotism in the choice of domestic versus foreign products. Journal of Advertising Research, 28(3), 25-32.

Han, C. M. (1989). Country image: halo or summary construct?. Journal of Marketing Research, 26(2), 222-229.

Han, C. M., \& Terpstra, V. (1988). Country-of-origin effects for uni-national and bi-national products. Journal of International Business, 19(2), 235-255.

Hanes, C., \& Wolcott, S. (2016). Research in Economic History (Volume 26). Bingley, UK: Emerald Group Publishing.

Heslop, L. A., \& Papadopoulos, N. (1993). But who knows where or when? Reflections on the images of countries and their products. In: N. Papadopoulos, \& L. A. Heslop (Eds.), Productcountry images: Impact and Role in International Marketing (pp. 39-75). New York, NY: International Business Press.

Hong, S., \& Wyer, R. S. (1989). Effects of country of origin and product-attribute information processing perspective. Journal of Consumer Research, 16(2), 175-187.

Howard, D. L. (1989). Understanding how American consumers formulate their attitudes about foreign products. Journal of International Consumer Marketing, 2(2), 7-22.
Huddleston, P., Good, L. K., \& Stoel, L. (2001). Consumer ethnocentrism, product necessity and polish consumers' perceptions of quality. International Journal of Retail \& Distribution Management, 29(5), 236-46.

Insch, G. S., \& McBride, J. B. (2004). The impact of country of origin cues on consumer perceptions of product quality: a binational test of the decomposed country of origin construct. Journal of Business Research, 57(3), 256-265.

Jaffe, E. D., \& Nebenzahl, I. D. (2001). National Image and Competitive Advantage: The Theory and Practice of Countryof-Origin Effect. Copenhagen, Denmark: Copenhagen Business School Press.

Johansson, J. K., Doughglas, S. P., \& Nonaka, I. (1985). Assessing the impact of country of origin on product evaluations: a new methodological perspective. Journal of Marketing Research, 22(4), 388-396.

Karunaratna, A. R., \& Quester, P. G. (2007). Influence of cognition on product component country of origin evaluation. Asia Pacific Journal of Marketing and Logistics, 19(4), 349-62.

Kaynak, E., \& Cavusgil, T. S. (1983). Consumer attitudes toward products of foreign origin: do they vary across product classes? International Journal of Advertising, 2(2), 147-157.

Kaynak, E., Kucukemiroglu, O., \& Hyder, A. S. (2000). Consumers' country-of-origin (COO) perceptions of imported products in a homogenous less-developed country. European Journal of Marketing, 34(9/10), 1221-1241.

Keown, C., \& Casey, M. (1995). Purchasing behavior in the Northern Ireland wine market. British Food Journal, 97(1), 17-20.

Klein, J. G., Ettenson, R., \& Morris, M. D. (1998). The animosity model of foreign product purchase: an empirical test in the People's Republic of China. Journal of Marketing, 62(1), 89-100.

Koschate-Fischer, N., Diamantopoulos, A., \& Oldenkotte, K. (2012). Are consumers really willing to pay more for a favorable country image? A study of country of origin effects on willingness to pay. Journal of International Marketing, 20(1), 19-41.

Kruskal, W. H., \& Wallis, W. A. (1952). Use of ranks in onecriterion variance analysis. Journal of the American Statistical Association, 47(260), 583-621.

Kumara, S., \& Canhua, K. (2010). Perceptions of country-of-origin: an approach to identifying expectations of foreign products. Brand Management, 17(5), 343-353.

Lala, V., Allred, A. T., \& Chakroborty, G. (2009). A multidimensional scale for measuring country image. Journal of International Consumer Marketing, 21(1), 51-66.

Laroche, M., Papadopoulos, N., Heslop, L. A., \& Moural, M. (2005). The influence of country image structure on consumer evaluations of foreign products. International Marketing Review, 22(1), 96-115. 
Lawrence, C., Marr, N. E., \& Prendergast, G. P. (1992). Countryof-origin stereotyping: a case study in the New Zealand motor vehicle industry. Asia Pacific International Journal of Marketing, 4(1), 37-51.

Leonidou, L. C., Hadjimarcou, J., Kaleka, A., \& Stamenova, G. T. (1999). Bulgarian consumers' perceptions of products made in Asia Pacific. International Marketing Review, 16(2), 126-142.

Levitt, T. (1983). The globalization of markets. Harvard Business Review, 61(3), 92-103.

Liefeld, J. (1993). Experiments on country-of-origin effects: review and meta-analysis of effect size. In: N. Papadopoulos \& L. Heslop (Eds.), Product-Country Images: Impact and Role in International Marketing (pp. 117-156). New York, NY: International Business Press.

Lin, L., \& Sternquist, B. (1994). Taiwanese consumers' perceptions of product information cues: country of origin and store prestige. European Journal of Marketing, 28(1), 5-18.

Marcoux, J. S., Filiatrault, P., \& Cheron, E. (1997). The attitudes underlying preferences of young urban educated Polish consumers towards products made in western countries. Journal of International Consumer Marketing, 9(4), 5-29.

McCaskill, A. (2016). Nearly 75\% of global respondents list country of origin as a key purchase driver. Retrieved March 26, 2020, from: https://www.nielsen.com/us/en/press-releases/2016/ nielsen-75-percent-of-global-consumers-list-brand-origin-askey-purchase-driver/

Nagashima, A. (1970). A comparison of Japanese and US attitudes toward foreign products. Journal of Marketing, 34(1), 68-74.

Oberecker, E. M., Riefler, P., \& Diamantopoulos, A. (2008). The consumer affinity construct conceptualization, qualitative investigation, and research agenda. Journal of International Marketing, 16(3), 23-56.

Opoku, R. A., \& Akorli, P. A. K. (2009). The preference gap: Ghanaian consumers' attitudes toward local and imported products. African Journal of Business Management, 3(8), 350-357.

Ozsomer, A., \& Cavusgil, S. (1991). Country of origin effects on product evaluations; a sequel to Bilkey and Nes Review. AMA Educators Proceedings (Vol. 2, pp. 269-277). Chicago, IL: American Marketing Association.

Papadopoulos, N., Heslop, L. A., \& Beracs, J. (1990). National stereotyping and product evaluations: an empirical investigation of consumers in a socialist country. International Marketing Review, 7(1), 32-47.

Peters, N. (2011). The country-of-origin effect on the perception of services: Entry mode decisions as a determinant of usability. München, Germany: GRIN Verlag GmbH.

Peterson, R. A., \& Jolibert, A. J. (1995). A meta-analysis of countryof-origin effects. Journal of International Business Studies, 26(4), 883-900.
Phau, I., \& Chao, P. (2008). Country-of-origin: state of the art review for international marketing strategy and practice. International Marketing Review, 25(4). https://doi.org/10.1108/ imr.2008.03625daa.001

Pharr, J. M. (2005). Synthesizing country-of-origin research from the last decade: is the concept still salient in the era of global brands. Journal of Marketing Theory and Practice, 13(4), 34-45.

Quelch, J. A., Joachinsthaler, E., \& Nueno, J. S. (1991). After the wall: marketing guidelines for Eastern Europe. Sloan Management Review, 32(2), 82-93.

Rockquemore, K. A., \& Brunsma, D. I. (2002). Socially embedded theories, typologies, and processes of racial identity among black/white biracial. The Sociological Quarterly, 43(3), 335-356.

Roth, K. P., \& Diamantopoulos, A. (2009). Advancing the country image construct. Journal of Business Research, 62(7), 726-740.

Roth, M. S., \& Romeo, J. B. (1992). Matching product category and country image perceptions: a framework for managing countryof-origin effects. Journal of International Business Studies, 23(3), 477-497.

Saffu, K., \& Scott, D. (2009). Developing country perceptions of high and low-involvement products manufactured in other countries. International Journal of Emerging Markets, 4(2), 185-199.

Saffu, K., \& Walker, J. (2006). The country-of-origin effects and consumer attitudes to "buy local campaign: the Ghanaian case. Journal of African Business, 7(1-2), 183-199.

Samiee, S. (2011). Resolving the impasse regarding research on the origins of products and brands. International Marketing Review, 28(5), 473-485.

Samiee, S. (1994). Customer evaluation of products in a global market. Journal of International Business Studies, 25(3), 579-604.

Samiee, S., Shimp, T., \& Sharma, S. (2005). Brand origin recognition accuracy: its antecedents and consumers' cognitive limitations. Journal of International Business Studies, 36(4), 379-397.

Schaefer, A. (1997). Consumer knowledge and country of origin effects. European Journal of Marketing, 31(1/2), 52-72.

Schooler, R. D. (1971). Bias phenomena attendant to the marketing of foreign goods in the US. Journal of International Business Studies, 2(1), 71-81.

Schweiger, S., Shimp, T., \& Shin, J. (1995). Consumer ethnocentrism: a test of antecedents and moderators. Journal of Academy of Marketing Science, 23(1), 26-37.

Shimp, T. A., \& Sharma, S. (1987). Consumer ethnocentrism: construction and validation of the CETSCALE. Journal of Marketing Research, 24(3), 280-289. 
Sohail, M. S. (2005). Malaysian consumers' evaluation of products made in Germany: the country of origin effect. Asia Pacific Journal of Marketing and Logistics, 17(1), 89-105.

Tan, C. T., \& Farley, J. U. (1987). The impact of cultural patterns on cognition and intention in Singapore. Journal of Consumer Research, 13(4), 540-544.

Thakor, M. V., \& Kohli, C. S. (1996). Brand origin: conceptualization and review. Journal of Consumer Marketing, 13(3), 27-42.

Thanasuta, K., Patoomsuwan, T., Chaimahawong, V., \& Chiaravutthi, Y. (2009). Brand and country of origin valuations of automobiles. Asia Pacific Journal of Marketing and Logistics, 21(3), 355-375.

Tse, D. K., \& Gorn, G. J. (1993). An experiment on the salience of country-of-origin in an era of global brands. Journal of International Marketing, 1(1), 57-76.

Urbonavičius, S., \& Gineikienè, J. (2009). Importance of the product country-of-origin factor on purchasing process in the context of globalization. Ekonomika, 85, 37-44.

Ustuner, T., \& Holt, D. B. (2010). Toward a theory of status consumption in less industrialized countries. Journal of Consumer Research, 37(1), 37-56.
Usunier, J. C. (2006). Relevance in business research: the case of country-of-origin research in marketing. European Management Review, 3(1), 60-73.

Verlegh, P. W. J., \& Steenkamp, J. B. E. M. (1999). A review and meta-analysis of country-of-origin research. Journal of Economic Psychology, 20(5), 521-546.

Wang, C. K. (1978). The effects of foreign economic, political and cultural environment on consumer's willingness to buy foreign products. Doctoral Dissertation. Texas A\&M University, College Station, TX.

Yavas, U., \& Alpay, G. (1986). Does an exporting nation enjoy the same cross-national commercial image?. International Journal of Advertising, 5(2), 109-119.

Zhang, Y. (1996). Chinese consumers' evaluation of foreign product: the influence of culture, product types and product presentation format. European Journal of Marketing, 30(12), $50-68$.

Zolfagharian, M., \& Sun, Q. (2010). Country of origin, ethnocentrism and bicultural consumers: the case of Mexican Americans. Journal of Consumer Marketing, 27(4), 345-357.

Zolfagharian, M., Saldivar, R., \& Sun, Q. (2014). Immigrant consumers, ethnocentrism, country of origin. Journal of Consumer Marketing, 31(1), 68-84. 